\title{
Educational Performance and the Role of Institutions
}

\author{
Renata Guidi ${ }^{1}$, Stanley Engerman ${ }^{2}$ Youssef Youssef $^{3}$
}

\begin{tabular}{l} 
ARTICLE INFO \\
\hline Article History: \\
Received 01.06.2019 \\
Received in revised form \\
04.09.2019 \\
Accepted \\
Available online 01.11.2019
\end{tabular}

\begin{abstract}
The analysis of institutional characteristics within the educational context is necessary due to the relevance that education, as a fundamental area of knowledge for the development of a country, exerts on society. In this sense, the present study seeks to understand how the institutional theory, in the perspective of Acemoglu and Robinson (2012), can be applied in the context of educational institutions. With regard to the methodological aspects, the study presents a literature review on the divergent perspectives of the institutional theory, followed by a discussion on the design by the theorists Acemoglu, Robinson and collaborators about this theory. The text provides an understanding on the connection of institutional factors and the educational outcome. An implication of this study is the opening of a new vision for analysis and reflection on institutional relationships that influence in the performance of educational institutions.
\end{abstract}

(c) All rights reserved

Keywords:

Institutional theory, efficiency, organizations, education

\section{INTRODUCTION}

One of the greatest challenges of the research on institutional influences on educational organizations is certainly the multidisciplinary approach that the issue raises to reach all its complexity. However, as indicate Fadul and Silva (2009), the inter, multi, and transdisciplinary approaches emerge as desirable practices in areas of knowledge that are dedicated to the study of complex phenomena of contemporary reality. In this context, the analysis through joint efforts from several disciplines is more relevant and reduces the risks of incurring simplistic analyses and representations of the real world (Ackoff, 1975).

Several studies point to the existence of a significant relationship between institutions and educational outcome (Hanushek and Woessmann, 2010; Acemoglu and Robinson, 2008; Bhaumik and Dimova, 2014; Woessmann, 2001). In this context, scholars have pointed to a connection between the political and economic incentives promoted by institutions, such as free market, ease of starting a business and existence of international partnerships, and the educational efficiency (Acemoglu, Robinson and Johnson, 2008; Hanushek and Woessmann, 2010; Wolf, 2004; Easterly, 2003).

In this line of thinking, Levin and Naylor (2007) ensure that an increase in the amount of financial resources is not sufficient to explain educational success, since the way to reduce the discrepancies of the educational outcomes among the countries is on improving institutional quality.

In earlier studies, Hanuskek (1981) has showed no strong or systematic relationship between school expenditures and student performance. Based on research findings, an increase of $60 \%$ on pupil spending, schools produce modest increases in achievement for all students in the core of academics area of mathematics and reading.

In this sense, it is stated that the quality in education involves structural changes in educational institutions (Gonard, Joumard and Price, 2007; Hanushek and Woessmann, 2008). In other words, the success of educational outcome depends not on the amount of allocated financial resources, but primarily on the institutional characteristics that drive the educational process (Woessmann, 2003).

The analysis to be develop in this study is based on the understanding of educational institutions and their correlation with the institutional differences that should be based on the conception presented by Acemoglu and Robinson (2012) in the construction of the institutional theory, drawn from the research they did about the origins of the power and its influence on the prosperity of a nation.

\footnotetext{
${ }^{1}$ Corresponding e-mail: renata.guidi@humber.ca, orcid.org/0000-0003-3580-2401, Humber College ${ }^{1}$

University of Rochester ${ }^{2}$, orcid.org/0000-0002-9976-1568

Humber College ${ }^{3,}$ orcid.org/0000-0003-3580-2401
} 
Although this study not aimed to explain thoroughly the essence of institutional theory, there is an intention to extract some ideas to be applied in the educational area, such as the view that the educational institution submits to economic institutions and that these, in turn, submits to a political power. This understanding opens the possibility of a more convincing explanation for the success or failure of education.

\section{INSTITUTIONAL THEORY AND GENERAL ASPECTS (OVERVIEW)}

Contemporary institutional theory has engrossed the attention of a range of scholars in the social sciences (Williamson, 1985; Scott, 1995; Tolbert and Zucker, 1996) and is employed to examine systems, starting from a micro view of interpersonal interactions to a macro view, visualizing global structures. Although the presence of "institutional scholars" in many disciplines have offered important opportunities for the exchange of scientific knowledge and enabled the cross-fertilization, a variety of approaches and oftenconflicting conclusions have limited academic speech (Scott, 2008).

In this way, institutional theory is not seen as a single school of thought, so that in academia is customary considering the existence of three institutional chains, the old institutionalism, based on the contributions of Veblen, Commons and Mitchell, the new institutional economics of Coase, Williamson, and North and the neo institutional current of Meyer and Rowan (Dimaggio and Powell, 1999; Scott, 1995).

According to DiMaggio and Powell (1999), the institutionalists differ in relation to the emphasis they give to micro and macro characteristics, in their reflections of cognitive and normative aspects of the institutions and on the importance that they assign to the interests and the relationship networks in the creation and dissemination of institutions.

However, the confidence that the institutional arrangements and social processes are important approaches the divergent institutional currents (Williamson, 2001; Dimaggio and Powell, 1999). Thus, the institutional approach known as the old institutionalism had its main contributions from the works by Veblen, Commons and Mitchell, which, influenced by the German historical school, criticized the orthodoxy of the neoclassical theory, the non-acceptance of the presumption of the rational man as a starting point and advocated the principle that economic analysis should be based on the study of the structure, the rules, and the behavior of the organizations (Valente, 2007; Scott, 1992).

However, the new institutional economics has Coase, Williamson, and North as the main authors. For them, "the institutions, regarded as economic and political instruments of collective action, would have as objective to reach the fundamental purposes of the modern society" (Valente, 2007). North, in turn, criticizes neoclassical economics in the economic decision-making process and its inability to explain the permanence of several economic institutions (Valente, 2007).

This second current, which basically states on the individual behavior of firms and individuals, is originated from the work by Coase (1937), but only began to be used later based on contributions from Williamson $(1979,1985)$. The main purpose of this current is to understand how are created and changed the governance structures, that is, the set of institutions that allows a particular type of transaction performs continuously.

The research field of the new institutional economics is distant from old institutionalism concerns, more focused on the individual behavior and the organization performance, in which the transactions and the market role have relevant function. This orientation for the market takes it away from old institutionalism.

The neo institutionalist current has its landmark with the publications of Meyer \& Rowan (1977). The main difference of this approach lies in the influence of social constructivism, adopted as official perspective of the new institutionalism (Dimaggio and Powell, 1991). Its main proponents affirm sharing a view of reality as socially constructed, and concentrated its efforts mainly on the analysis of organizations inserted in a sector, field or company (Fonseca, 2003; Ventura, 2004).

Institutional theory wins space in organizational studies by providing ways to understand implicit standards and uniformity within the organizations. Consequently, it provides important contributions to the 
management of organizations, since the processes are the results not only of human action, but also of the interactions in the social and political context (Fachin and Mendonça, 2003).

Dacin, Goodstein \& Scott (2002) argue that the institutional theory is an explanation for individual and organizational actions. Modern societies are structured by rules and standards that govern and restrict the actions of individuals, entities and companies in which people organize themselves, as already discussed in the autopoietic theory (Maturan and Varela, 1979), in which it shows the clear difference between organization, understood as a set of relationships that occur among the components; and structure, which comprises the components and relationships that make up a particular unit, performing its organization. To make use of these rules and standards, formal or informal, the institutions reduce the risk of uncertainty, having more chances to ensure good coexistence and achieve the best possible social welfare.

For this study, institutions are seen using the concept established by North (1993), such as the rules of the game in a society or, more formally, as humanly invented constraints that shape human interaction, organized under the scope of formalized and written rules and laws - formal institutions - and under a set of rules or conduct codes, formed within the society - informal institutions - aiming at ordering the interactions among individuals and between them and their respective organizational forms. As a result, these institutions create economic, social or political incentives in human exchanges.

In studies related to institutional theory, in most cases, a differentiation between institution and organization are made: if the institutions are the rules of the game, the organizations are the players (North, 1990, p. 13). Organizations are composed by groups of individuals dedicated to any activity performed with a particular purpose.

According to the institutionalists, the organizations are inserted in an environment consisting of rules, beliefs and values, created and consolidated through social interaction. In this sense, its survival depends on the ability of meeting the shared guidelines collectively, whose permanent support contributes to the success of the implemented strategies and, consequently, to the full internal operation. Thus, under the same environmental constraints, the organizations also compete for the scope of institutional legitimacy, what makes its practice more homogeneous or isomorphic (Meyer and Rowan, 1992; Scott, 1987, 1992).

However, the tendency to homogenize does not invalidate the competitive demands, as many of the empirical research done based on this perspective seems to suggest. In analytical terms, "competitive and institutional processes are not necessarily opposite" (Dimaggio and Powell, 1991, p. 183).

In this institutional point of view, Greve (2018) highlights that the organizational performance is linked to the ability of the organization to understand and manage the symbolic resources, through the rules and standards of conduct socially valued, which meet the expectations of the actors in the context in which they operate. The attention of the organization to these standards and values, socially constructed and introduced, guarantees its permanence and legitimacy in the environmental context, allowing it more access to material and economic resources (Scott, 1995).

Thereby, the prescriptive approach of organizational analysis keeps prevailing, since organizations seek structural arrangements increasingly efficient (Hannam and Freeman, 1989).

Therefore, for the effect of this study, the perspective of Acemoglu, Robinson and collaborators is adopted on institutional theory, based on the ideas of the new institutional economics (NEI), which had as one of the main concerns to show that the institutions of a country may be more or less favorable to economic development.

\section{INSTITUTIONAL THEORY IN THE CONCEPTION OF ACEMOGLU \& ROBINSON}

The concept of institutional theory in the perspective of Acemoglu \& Robinson (2012) had its origin in the studies conducted by North and Thomas (1973), North (1982), and North, Wallis and Weingast (1989). The studies considered the institutional perspective as an inductor capable of causing an incentive structure for society. 
In the view of North and Thomas (1973), individuals should be encouraged to undertake socially desirable activities that add value in the creation of economic growth. However, any kind of economic growth - innovation, economy of scale, education, and capital accumulation - can only thrive in effective economic organizations, later called inclusive economic institutions (North, 1990; Engerman and Sokoloff, 1997; Acemoglu, Johnson and Robinson, 2000, 2002).

Denzau and North (1994) point out that, while a minority of companies shows economic institutions designed to provide property rights, equality of conditions and basic public goods for economic growth, most of which is structured to maximize the incomes of an elite and monopolize political power (North, 1982).

In this sense, North, Wallis and Weingast (1989) advance in the discussion when seeking to understand the basic dynamics between the political and economic spheres of societies. The authors emphasize the importance of political institutions in the production of a property structure that maximizes the economic product of a society. In other words, only an efficient political system is able of producing an adequate structure of property that, when defined and guaranteed, efficient arrangements will take organizations and individuals to invest in productive economic activities, especially in the accumulation of capital and knowledge. The authors argue that the imperfection of the political market is based on the constitution of inefficient economic institutions (Boudreaux et al, 2019).

In this line of thought, Acemoglu and Robinson (2012) propose a new perspective of institutional theory based on the concept of political and economic institutions as essential to explain why nations fail and thrive, whereas each society works with a set of economic and political rules created and enforced together by the State and by citizens (Acemoglu, Robinson and Johnson, 2000, 2002, 2008; Acemoglu and Robinson, 2006, 2008, 2012).

Economic institutions shape economic incentives: incentives to reach more education to make it possible to innovate and adopt new technologies. While the political process determines for which economic institutions the people will live, the political institutions dictate how this process works.

The economic and political institutions are classified by Acemoglu and Robinson (2012) as inclusive and extractive. Inclusive economic institutions are defined as those that enable and encourage participation of the great mass of population in economic activities that make the best possible use of their talents and skills, ensure private and intellectual property rights, and encourage the emergence of new companies, able to bring new technologies and economic opportunities not only for the elite, but also for a large portion of society. Meanwhile, the extractive economic institutions are characterized as opposite, by concentrated income into a privileged elite (Acemoglu and Robinson, 2012).

The development of inclusive economic institutions, however, depends on the emergence of political institutions also inclusive. Acemoglu and Robinson (2012) state that the inclusive economic institutions are unable to support or be supported by extractive political institutions; or become extractive, favoring strict interests of power holders, or the own economic dynamics destabilizes the extractive political institutions and paves the way for the emergence of inclusive political institutions.

Buoyed by these concepts, inclusive political institutions can be conceptualized as those that promote plurality and political centralization, that is, serve a broad range of different interests and represent a broad range of political actors.

On the other hand, extractive political institutions are designed to protect the interests of a privileged elite and to restrict the political participation of a select group of allied actors in order to impose few restrictions on the power exercise of this elite (Acemoglu and Robinson, 2008).

On theoretical design of Acemoglu and Robinson (2012), the policy determines the economy. Inclusive political organizations promote inclusive economic institutions because they stimulate innovation, ensuring property rights. However, extractive political institutions fear the technological innovation and the "creative destruction" caused by the inclusive economic institutions, since the wealth spread by the society may harm the foundations of political power concentrated in the hands of a few. 
In this perspective, Acemoglu and Robinson (2012) point out that technological innovation is only feasible in the presence of inclusive political institutions, since power holders fear the innovation and the destabilizing impact of "creative destruction".

This interaction between political and economic institutions determine the causes of prosperity or poverty of a society. Inclusive economic institutions, which ensure property rights, create equal conditions for all and encourage investments in new technologies and skills, have a better chance to lead to economic growth than the extractive, which are structured so that a few can extract many resources and are unable to protect the property rights or provide incentives for economic activity.

\section{INSTITUTIONAL THEORY APPLIED TO THE EDUCATIONAL CONTEXT}

To understand the relationship between the theoretical proposal of Acemoglu and Robinson (2012) and the educational system is necessary for the importance that education, as a fundamental area of knowledge for the development of a country, exerts on society. In this context, it is possible to affirm that the existence of a connection between the educational performance and the institutional factors, namely: respect for intellectual property rights, free markets, promotion of entrepreneurship, and education performance (Acemoglu et al., 2008; Hanushek and Woessmann, 2010; Wolf, 2004; Easterly and Levine, 2003).

For example, when considering the correlation between institutional variables, educational outcomes, and economic performance, Lim and Adams-Kane (2009, p. 22) have concluded that "the efficiency of the institutions is central for learning and educational performance".

Recent controversial currents about the increase of expenditure on education show that, in order to reduce the inequality of educational outcomes among countries, an increase in investment destined to education is no longer enough to guarantee an improvement in terms of educational quality (Levin and Naylor, 2007).

For Gonard, Jourmard and Price (2007), the advance in the education quality is given through structural changes in educational institutions. This implies that the efficiency of the institutional structure provides an impact on the education development, since it determines the use of resources and incentives present in human relations (Rajkumar and Swaroop, 2008). In other words, the success of educational outcome does not depend primarily on the spent resources, but depend on the institutional characteristics along the educational process (Woessmann, 2003).

There is a growing evidence that institutional factors of the educational system exert important effects in educational outcome (Bishop and Woessemann, 2004). The institutional aspects that have been shown to influence considerably the student performance are the presence of standardized tests (Bishop, 1997, 1999); centralization and political autonomy (Woessmann, 2003); unionization degree of the teacher (Hoxby, 1996); the influence of parents (ROUSE, 1998); and competition in the educational system (Hoxby, 1994, 2000; Rouse, 1998).

One reason whereby the institutions exert crucial role in educational outcome may be that the public schools dominate the performance of basic education in a good share of the world. Supporting this subject, Ménard (2000) believes that the public system of education may not have the appropriate incentives to improve student performance or even reduce the expenses.

In this sense, it is consensus that the behavior of maximized performance in private sector is due to the market competition, imposing penalties on companies that fail to use their resources effectively.

However, for Bishop and Woessmann (2004), the relative absence of competition in the educational market tends to weaken the incentives to improve quality while keeping low costs. Furthermore, in the public system of education, the ability of parents and students to ensure the education quality is limited by a series of obstacles, transferring to the Government, officials and teachers the responsibility for adequate quality control measure (Kahu and Nelson, 2017). 
In this context, Landsburg (1993, p. 3) summarizes "what most economists claim in four words: people respond to incentives." Therefore, to understand the economic forces present in the educational market, it is necessary to analyze the incentives that influence the different actors involved in the educational outcome, as well as the different institutional structures that create these incentives.

Generally, institutions are seen as constraints humanly invented, constituting the ground rules of a society (North, 1990). Within the educational system, institutions influence the distribution of power in decision-making among the different involved actors. A group of institutions creates a system of property rights, such as rights to these actors use resources and limit the competition for resources. In other words, the institutions determine who is eligible to make decisions on the use of resources in different areas. Additionally, institutions define the provision of information in the system, as well as the rewards and penalties of the actors in response to their actions (Furubotn and Richter, 1997). Therefore, institutions define and limit the set of possible choices of actors and thus form the prevailing incentive structure.

While institutions are the ground rules of a society, people who are players in this game act within a system of rules. Based on that the individual actors behave rationally, these seek to maximize their duties subject to the restrictions defined by the institutions. Therefore, the actors respond to the incentives created by the conjunction of determined institutions.

For Bishop and Woessmann (2004), the behavior of people involved in the educational process is reflected in their decisions about the allocation of resources among different functional categories (e.g. number and wages of teachers), as well as on the efficiency of the use of such resources, which, in turn, affects the educational outcome, measured by the performance of students.

Consequently, institutions influence the student performance through the creation of a system of rights that define the allocation of resources, establishing incentives to direct the behavior of actors in a particular direction. In the explanation of North (1994, p. 359) on the economic performance, "institutions form an incentive structure of a society, being the political and economic institutions, as a result, the underlying determinants of the economic performance". Based on this same consequence, the political and economic institutions are the underlying determinants of the educational performance (Hanushek and Woessmann, 2008; Bishop and Woessmann, 2004; Woessmann, 2003).

\section{Previous studies}

In this point of discussion, it is valid to highlight that the international literature has evolved into the discussion of institutional effects, in the perspective of Acemoglu \& Robinson, on the performance of educational institutions.

Baciu (2012) analyzes the performance of 400 schools in Romania from the perspective of institutional efficiency, shown on Acemoglu and Robinson, providing ways to perform a comparative analysis between the education of Romania and the OECD countries.

It is used the methodology suggested by Gonard, Joumard and Price (2007), known as composite indicator for comparative analysis, with this indicator grouped into three dimensions: 1) ability to allocate resources efficiently - characterized by the decentralization capacity, i.e. have clearly defined responsibilities and direct resources to specific needs (teachers, public procurement); -2) efficiency in budget management marked by a focus on the budget outcome, i.e. meeting the established target and managerial autonomy, measured by the flexibility of wage changes of teachers and promotions, as well as the flexibility of the allocation of resources for schools; -3) market efficiency - indicated by the use of benchmarking, comparison of outcomes between schools and free choice of schools to establish their own policies.

The research data were achieved through the result compilation from the questionnaires applied in schools, using the algorithm. The main conclusion of the study is based on the knowledge that the educational outcome may not be interpreted outside the institutional context, confirming the gap between the education of Romania and the OECD countries. 
This author suggests that low educational quality of Romania, in terms of cognitive skills and performance, is related to certain institutional characteristics of the educational system, as the lack of managerial and budgetary autonomy, the excessive centralization of political actors and the high level of corruption, which leads to inefficiency (Baciu, 2012).

Hanushek and Woessmann (2010) performed a comparative analysis among developing countries, seeking to measure the impact of institutional factors, socioeconomic characteristics, and school resources on student performance. To this end, the statistical technique of multiple regression was used to assess this effect. As dependent variable, they opted for the outcome of the educational process, measured by notes from standardized international tests in the disciplines of mathematics, sciences and Portuguese.

The independent variables were socioeconomic characteristics from the chosen students, obtained through the family income and value in books that students have in their home, reached in the database of PIRLS dataset. The institutional factors included the teachers' autonomy, accompanying measures of studentteacher evaluation and budget management, as well as educational resources, which consisted in the size of the classroom, availability of didactic materials and school location. As a conclusion, the study confirms the results obtained from the research conducted in 2003, when Woessmann suggests strong influence of socioeconomic characteristics of the student and institutional factors on educational performance, while school resources showed low influence.

In the study performed by Lim and Adams-Kane (2009), the authors seek to establish a link between the institutional quality and the effect on economic growth, considering the impact of education. To this end, they adopt the multiple regression method in a two-stage strategy. Initially, they seek to determine the Government effectiveness, estimating the production function of the national level of education, which includes institutional governance and inputs to schooling as covariates. Thereupon, they use the estimates of the first stage as human capital variables to make use of multiple regression from the income.

This method not only provides a new estimate of the impact of Government indicators in educational outcomes among countries, but also address the endogeneity concerns that arise when direct measures of education are used in such regressions. The authors demonstrate that the quality of the institutions is essential to learning and education, so that the Government role in the growth of a country operates primarily in establishing institutions that foster learning and the accumulation of human capital, reducing the absenteeism of teachers in schools, the amount of informal payments and corruption in schools.

Gonard, Joumard and Price (2007) present a set of indicators as a result of the experiences of OECD Member countries, which reflect institutional and political characteristics of educational systems, constructed from questionnaires answered by 26 countries that make up the entity. Such indicators provide a vision of the institutional structure of education both from elementary school and from the high school that can be used in the analysis of international differences in order to determine the efficiency of the educational public sector.

These authors group the indicators in three dimensions, each represented by two intermediate indicators: a) ability to prioritize and allocate resources efficiently, symbolized by the indicators that measure the decentralization ability of central Government in relation to local authorities and to the correspondence in answer specific needs; b) efficiency in the management of expenses, translated by the public school system's ability to focus on the results and managerial autonomy of schools; c) efficiency in the provision of services, represented by the benchmarking indicators, i.e. by identifying best practices and inefficiencies in the schools, with the aim of stimulating competition among schools, as well as by user choice indicator, measured by the ability of students to choose their own schools.

This study brings great contribution to the efficiency analysis of educational institutions, by providing indicators that allow assessing the institutional and political characteristics of the educational system of a country.

Woessmann (2003) estimates the effect of family background, resources and institutional characteristics in student performance in mathematics and sciences, using a database of over 260,000 students from 39 countries. To this end, the method of multiple regression was used, with the student's educational performance as dependent variable, related to family background variables, evaluated by means of standard questionnaire; resources, measured by a specific test of evaluation, which includes expenses by students, 
classroom size and attributes relevant to the teacher; and characteristics of the institutions, through measures of documentary research in accordance with the following categories: distribution of responsibility between school and administration, distribution of responsibility in different administrative levels, the teacher's influence, influence of parents on school and incentives to students, measured by their study time in schools.

The author demonstrates that the differences in the incentives of the institutional structure, determined by the characteristics of the educational system institutions, imply strongly in the student performance. It was also found a strong positive correlation between the family background and the student performance. However, the result of students cannot be attributed to the amount of resources offered by the educational system.

Thereby, in addition to the concern of many studies to investigate the role of the family background and the amount of resources on student performance, this study brings an important contribution when it concludes that international differences in institutional arrangements of the educational system from surveyed countries make it possible to understand the differences of the student performance (Woessmann, 2003).

Among the reviewed studies, there is a link between the institutional factors and the educational institutions, denoting that the educational performance is a result of political and economic incentives present in these institutions.

\section{FINAL CONSIDERATIONS}

The purpose of this study was to understand the institutional relations within education system, based on institutional theory in the perspective of Acemoglu \& Robinson (2012). Theoretical support presented the main conceptual elements to narrow the object of research, especially the relationship between institutional factors and educational outcome. The incipient literature on the related subject was noticeable, mainly as regards the presence of quantitative and qualitative parameters in the context of education.

The theoretical elements, resulting from the literature review, denoted that the quality of the institutions is essential to learning and education, since these institutions influence the student performance. Thus, it is suggested that the dominant political actors of a country establish institutions that encourage learning, accumulation of human capital and the combat of corruption in schools, in order to keep advances in educational quality of countries. The research allows to affirm that people respond to incentives, however, the partly absence of competition in the educational market may weaken incentives to improve the quality or even reduce expenses. Thereby, it is crucial to understand the political and economic forces in the educational market to analyze the incentives that influence the different actors involved in the educational outcome, as well as the institutional structures that create these incentives.

As future perspective for the present study, it can be considered the use of quantitative methods that allow analyzing empirically the reality of a region or school. Allied to this, the inclusion of variables that make it possible to identify the influence of family background, race, institutional factors, among others in the educational outcome of students. This suggestion comes from the studies of Camps and Engerman (2012), when analyzed the impact of race in Latin American education quality. For the authors, the income inequality found in the 21st century and the racial structure present in the countries of Latin America strongly influence the formation of human capital.

\section{REFERENCES}

Acemoglu, D., \& Robinson, J. A. (2013). Why nations fail: The origins of power, prosperity, and poverty. Crown Business.

Acemoglu, D., Johnson, S., \& Robinson, J. A. (2000). The colonial origins of comparative development: An empirical investigation (No. w7771). National bureau of economic research.

Acemoglu, D., Johnson, S., \& Robinson, J. A. (2002). Reversal of fortune: Geography and institutions in the making of the modern world income distribution. The Quarterly journal of economics, 117(4), 1231-1294. 
Acemoglu, D., Robinson, J., \& Johnson, S. (2008). Institutions as the fundamental cause of long-run growth. Handbook of Economic Growth.

Acemoglu, D., \& Robinson, J. A. (2005). Economic origins of dictatorship and democracy. Cambridge University Press.

Acemoglu, D., \& Robinson, J. A. (2008). Persistence of power, elites, and institutions. The American Economic Review, 98(1), 267-293.

Ackoff, R. L. (1975). Planejamento de pesquisa social. Editôra Herder.

Baciu, L. (2012). An analysis of the Romanian compulsory education from the perspective of institutional efficiency. Procedia-Social and Behavioral Sciences, 46, 2056-2067.

Bhaumik, S. K., \& Dimova, R. (2014). Good and bad institutions: is the debate over? Cross-country firmlevel evidence from the textile industry. Cambridge journal of economics, 38(1), 109-126.

Bishop, J. H. (1997). The effect of national standards and curriculum-based exams on achievement. The American Economic Review, 87(2), 260-264.

Bishop, J. H. (1999). Are national exit examinations important for educational efficiency?. Swedish Economic Policy Review, 6, 349-398.

Bishop, J. H., \& Wößmann, L. (2004). Institutional effects in a simple model of educational production. Education Economics, 12(1), 17-38.

Boudreaux, C., Nikolaev, B.\& Klein, P. (2019). Socio-cognitive traits and entrepreneurship: The moderating role of economic institutions. Journal of Business Venturing. 34(1), 178-196.

Camps, E. \& Engerman, S. The impact of race and inequality on human capital formation in Latin America during the nineteenth and twentieth centuries. Journal of Development Economics, 57(2).

Coase, R. H. (1937). The nature of the firm. Economica, 4(16), 386-405.

Dacin, M. T., Goodstein, J., \& Scott, W. R. (2002). Institutional theory and institutional change: Introduction to the special research forum. Academy of management journal, 45(1), 45-56.

Powell, W. W. (1999). El nuevo institucionalismo en el análisis organizacional (No. 302.35 P6Y.).

Denzau, A. T., \& North, D. C. (1994). Shared mental models: ideologies and institutions. Kyklos, 47(1), 331.

DiMaggio, P. J., \& Powell, W. W. (Eds.). (1991). The new institutionalism in organizational analysis (Vol. 17). Chicago, IL: University of Chicago Press.

Easterly, W., \& Levine, R. (2003). Tropics, germs, and crops: how endowments influence economic development. Journal of monetary economics, 50(1), 3-39.

Engerman, S. L., \& Sokoloff, K. L. (1997). Factor endowments, institutions, and differential paths of growth among new world economies. How Latin America Fell Behind, 260-304.

Fachin, R. C., \& Mendonça, J. R. C. (2003). Selznick: uma visão da vida e da obra do precursor da perspectiva institucional na teoria organizacional. Organizações, instituições e poder no Brasil. Rio de Janeiro: FGV, $29-45$.

Fadul, É. M. C. (2009). Limites e Possibilidades Disciplinares da Administração Pública e dos Estudos Organizacionais/Disciplinary Limits and Possibilities of Public Administration and Organizational Studies. Revista de Administração Contemporânea, 13(3), 351.

Fonseca, V. D. (2003). A abordagem institucional nos estudos organizacionais: bases conceituais e desenvolvimentos contemporâneos. Organizações, instituições e poder no Brasil. Rio de Janeiro: FGV, 58.

Furubotn, E. G., \& Richter, R. (1997). Institutions and economic theory: The contribution of the new institutional economics. University of Michigan Press.

Gonand, F., Joumard, I., \& Price, R. (2007). Public spending efficiency: institutional indicators in primary and secondary education. OECD Economic Department Working Papers, (543), 1.

Greve, H. (2018). Goal Selection Internally and Externally: A Behavioral Theory of Institutionalization. International Journal of Management Review. (20), 19-38.

Hannan, M. T., \& Freeman, J. (1989). Organizational ecology. Cambridge: Harvard University Press.

Hanushek, E. A., \& Wößmann, L. (2010). Education and Economic Growth.

Hanushek, E. A., \& Wößmann, L. (2007). The role of education quality for economic growth.

Hanushek, E. A. (1981). Throwing money at schools. Journal of policy analysis and management, 1(1), 19-41.

Hoxby, C. M. (1994). Do private schools provide competition for public schools? (No. w4978). National Bureau of Economic Research. 
Hoxby, C. M. (1996). How teachers' unions affect education production. The Quarterly Journal of Economics, 111(3), 671-718.

Hoxby, C. M. (2000). The effects of class size on student achievement: New evidence from population variation. The Quarterly Journal of Economics, 115(4), 1239-1285.

Kahu, E. \& Nelson K. (2017). Student engagement in the educational interface: understanding the mechanisms of student success. Higher Education Research \& Development, 37(1).

Landsburg, S. E. (1993). The Armchair Economist economics and Everyday Life. New York: Macmillan.

Levin, B., \& Naylor, N. (2007). Using resources effectively in education. In Intelligent leadership (pp. 143158). Springer Netherlands.

Lim, J. \& Adams-Kane, J. Institutions, Education, and Economic Performance. Paper presented at the annual meeting of the Midwest Political Science Association 67th Annual National Conference, The Palmer House Hilton, Chicago, IL, Apr 02, 2009.

Maturana, H. R., \& Varela, F. J. (1979). Autopoiesis and cognition: The realization of the living. London: Reidl.

Meyer, J. W., \& Rowan, B. (1977). Institutionalized organizations: Formal structure as myth and ceremony. American journal of sociology, 83(2), 340-363.

North, D. C. (1990). Institutions, institutional change and economic performance. Cambridge university press.

North, D. (1993). The Sveriges Riksbank Prize in Economic Sciences in Memory of Alfred Nobel: autobiography. The Nobel Foundation.

North, D. C., \& Thomas, R. P. (1973). The rise of the western world: A new economic history. Cambridge University Press.

North, D. Structure and Change in Economic History. Nova York: W.W. Norton e Co., 1982.

North, D. C., \& Weingast, B. R. (1989). Constitutions and commitment: the evolution of institutions governing public choice in seventeenth-century England. The journal of economic history, 49(04), 803-832.

Rajkumar, A. S., \& Swaroop, V. (2008). Public spending and outcomes: Does governance matter?. Journal of development economics, 86(1), 96-111.

Rouse, C. E. (1998). Private school vouchers and student achievement: An evaluation of the Milwaukee Parental Choice Program. The Quarterly journal of economics, 113(2), 553-602.

Scott, W. R. (2008). Approaching adulthood: the maturing of institutional theory. Theory and society, 37(5), 427.

Scott, W. R. (1995). Institutions and organizations: Ideas, interests, and identities. Sage Publications.

Scott, W. Introduction: from technology to environment. In: Meyer, J., Scott, R. (Ed.). Organizational environments: ritual and rationality. Updated Edition. London: Sage, 1992.

Scott, W. R. (1987). The adolescence of institutional theory. Administrative science quarterly, 493-511.

Tolbert, P. S., \& Zucker, L. G. (1999). The institutionalization of institutional theory. Studying Organization. Theory \& Method. London, Thousand Oaks, New Delhi, 169-184.

Valente, N. (2007). Breves Considerações sobre a Nova Economia Institucional. Conselho Federal de Economia. Disponível em: <www.cofecon.org.br>. Acesso em: 30 out. 2016.

Ventura, E. (2004). Dinâmica de institucionalização de práticas sociais: estudo do movimento pela responsabilidade social no setor bancário. Projeto de doutorado- Ebape/FGV, Rio de Janeiro.

Williamson, O. E. (2000). The new institutional economics: taking stock, looking ahead. Journal of economic literature, 38(3), 595-613.

Williamson, O. E. (1985). The economic institutions of capitalism: Firms, markets, relational contracting (Vol. 866). New York: Free Press.

Williamson, O. E. (1979). Transaction-cost economics: the governance of contractual relations. The journal of Law and Economics, 22(2), 233-261.

Woessmann, L. (2001). Why students in some countries do better. Education Next, 1(2).

Woessmann, L. (2003). Schooling resources, educational institutions and student performance: the international evidence. Oxford bulletin of economics and statistics, 65(2), 117-170.

Williamson, O. E. (1985). The economic institutions of capitalism: Firms, markets, relational contracting (Vol. 866). New York: Free Press.

Wolf, A. (2004). Education and economic performance: Simplistic theories and their policy consequences. Oxford review of economic policy, 20(2), 315-333. 